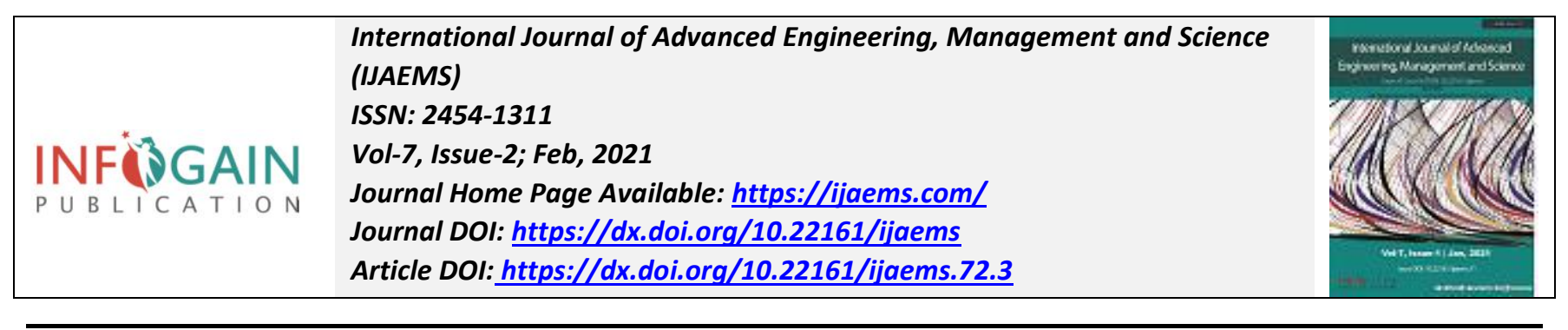

\title{
Handle Assembler Validation
}

\author{
Flores Sánchez Verónica ${ }^{1}$, Aguilar Peña Diana Jazmín², Vallejo Hernández Arely ${ }^{3}$, \\ Vásquez Rosas Sergio ${ }^{4}$, Hernández Sánchez Uriel Alejandro ${ }^{5}$, Chama Esteban José Luis ${ }^{6}$
}

\author{
${ }^{1,2}$ Department of IMI, Universidad Tecnológica del Centro de Veracruz, Veracurz, México \\ ${ }^{3}$ Department of ER, Universidad Tecnológica del Centro de Veracruz, Veracurz, México \\ ${ }^{4,5,6}$ Department of DNM, Universidad Tecnológica del Centro de Veracruz, Veracurz, México
}

Received: 02 Nov 2020; Received in revised form: 11 Jan 2021; Accepted: 02 Feb 2021; Available online: 14 Feb 2021

C2021 The Author(s). Published by Infogain Publication. This is an open access article under the CC BY license

(https://creativecommons.org/licenses/by/4.0/).

\begin{abstract}
The present study was carried out in a company that manufactures 1-liter jugs, the daily production to be covered is at least 9500 1-liter bottles per shift, during the last months the production quota was not being met, since in the area handle assembly was lost about 12 seconds.

The objective of this project is to solve the problem presented in the production, reducing the time in the placement of the handle, the minimum production quantity per shift can be met. To provide a solution, an Ishikawa diagram was used using the 6 M's methodology where it was obtained and it was decided to solve the lack of an electro-pneumatic handle setting equipment, since, in the production area, there is no such system for so it was decided to build one so that it cannot affect the workspaces.

When building the assembler, the handle can be installed in 3 seconds under a single operator, that is, the installation time improved and a salary was reduced, also avoiding problems caused by insufficient personnel. In this way, the purpose for which the assembler was developed is fulfilled; the validation of it through ANOVA is presented below.
\end{abstract}

Keywords-ANOVA, validation, assembler.

\section{INTRODUCTION}

To raise production rates it is vital that all the components that make up a process are in their best state and synchronicity, this avoids delays, stoppages, waste and any factor that means losses for the company.

Within the company case study, the objective was defined to reduce the time the placement of handles, the handle assembler that is tested in this study works with an electro pneumatic system, which applies force and displacement on the handle in the neck of the bottle for placement.

With the use of the prototype, a production per shift of 9500 bottles is achieved, while approximately 7,200 are obtained manually, which reflects a deficit of $25 \%$, causing that for each hour 288 more bottles should be placed, therefore, it is necessary the transfer of personnel.

THE ASSEMBLER CAN only attach one handle to a single bottle at a time, limiting the amount of final product. The assembler shortens the time from 12 to just 3 seconds, streamlining the process.

The present invention aims to validate a device for placing a handle on a bottle or carafe, a machine that integrates the device for placing a handle on a bottle or carafe, a procedure for placing the handle on a bottle or carafe, and a handle that can be placed on a bottle or carafe. . The device for placing a handle on a bottle or carafe has a series of arms that allow the handle to be picked up from a handle feeder means and placed in a bottle or carafe.

The machine that integrates the above device has handle feeder means that position each of the handles in such an arrangement that allows the device for placing the handle on the bottle or carafe to pick up the handles from said handle feeder means.

Likewise, the machine that integrates the device for placing a handle on a bottle or carafe has feeding means for bottles or carafes that allow them to be directed 
towards the device for placing the handle. The procedure for placing the handle on the bottle or carafe picks up the handle from the handle feeder device and places it on the bottle or carafe. (Ruiz, 2010)

\section{OBJECTIVE}

Validate the prototype that reduces the time for placing handles on the one-liter bottles, using ANOVA.

\section{HYPOTHESIS}

With the jointer, the time in placing the handle on the bottle will be reduced from 12 to 3 seconds, this for only one person.

\section{JUSTIFICATION}

With this project, the workers of the company will be able to place a greater number of handles in a shorter time, the profits will increase, since it will not be invested in more personnel or they will have to change the area; The production time will be reduced and at the same time, the machine will not stop due to bottle accumulation.

\section{ANALYSIS OF VARIANCE (ANOVA)}

To evaluate the experimental conditions of the machine we will use a statistical method known as analysis of variance or ANOVA (for its acronym in English Analysis of variance), which is in charge of analyzing the means, to evaluate whether an event or characteristic influences or not the operating results.

As in any experimental study of a phenomenon, a hypothesis is raised, this case is not the exception, known as the null hypothesis or also called $\mathrm{H} 0$, when making a change in some characteristic it is thought that this will not affect the performance of what is is studying and we call this $\mathrm{H} 0$, in order to predict the behavior and verify if it changes or not.

To run the ANOVA, a continuous response variable is needed, which is the one we want to measure and observe how it reacts with the established changes, for this case it will be the time of placement of the handle and a categorical factor, which are the changes in the study, in this case it will be the different methods of placing the handle.

A series of samples will be selected at random, considering the operating characteristics and the factors to be evaluated; the time it takes to place the handle the different methods was taken.

\section{TECHNOLOGICAL EVALUATION.}

After defining the factor to be modified, we propose to create an automatic handle jointer. For this, the study of materials to be used is carried out.

\section{PNeUMATIC CYLINDER}

For the development of the jointer is necessary to have the technical data of the pneumatic cylinder, whose function is to place the handle.

Table 1 is shown below with data from the pneumatic cylinder.

Table 1 Technical data of the pneumatic cylinder

\begin{tabular}{ll}
\hline Attribute & Value \\
Action & Double \\
Maximum pressure & $10 \mathrm{bar}$ \\
Damping type & Padded \\
Body dimensions & $20 \mathrm{~mm}$ diameter $\mathrm{x}$ \\
& $145 \mathrm{mmo}$ \\
Maximum operating & $80^{\circ} \mathrm{C}$ \\
temperature & \\
Length & $145 \mathrm{~mm}$ \\
Minimum operating & $-20{ }^{\circ} \mathrm{C}$ \\
temperature & \\
Diameter & $20 \mathrm{~mm}$ \\
\hline
\end{tabular}

With the information in table 1 the plunger area is calculated.

Equation $1 \quad f^{\prime}=\frac{\mathscr{H}}{A}$

Where:

$\mathrm{P}=$ pressure $(\mathrm{Pa})$

$\mathrm{F}=$ force $(\mathrm{N})$

$\mathrm{A}=\operatorname{area}\left(\mathrm{m}^{2}\right)$

To carry out the tests at different pressure values, the areas of the cylinder are calculated with equation 1.

At the end of the tests we could see that the force was not enough to place the handle.

Therefore, it was carried out at different pressures and the results are presented below. See table 2 . 
Table 2 Tests with different values

\begin{tabular}{cccccc}
\hline \multicolumn{5}{c}{ Pressure } & \multicolumn{3}{c}{ Strength (N) } & $\begin{array}{c}\text { Stre } \\
\text { ngth } \\
\mathbf{m}^{\mathbf{2}}\end{array}$ & bar & Pa & Extension & Retraction & \\
1 & 0.980665 & 98066.5 & 11.11 & 8.33 & No \\
2 & 1.96133 & 196433 & 22.25 & 16.69 & No \\
3 & 2.941995 & 294199.5 & 33.33 & 25 & No \\
4 & 3.92266 & 392266 & 44.44 & 33.34 & OK \\
5 & 4.903325 & 490332.5 & 55.55 & 41.67 & OK \\
6 & 5.88399 & 588399 & 66.66 & 50 & OK \\
7 & 6.864655 & 686465.5 & 77.77 & 58.34 & OK \\
8 & 7.84532 & 784532 & 88.88 & 66.68 & OK \\
9 & 8.825985 & 882598.5 & 99.99 & 75.02 & OK \\
10 & 9.80665 & 980665 & 111.1 & 83.35 & OK \\
\hline
\end{tabular}

The pressure is shown in three different measurement units, $\mathrm{kg} / \mathrm{cm}^{2}$ which is the pressure with which the tests were carried out, in bar to identify its value in this measure and avoid exceeding the limit of the cylinder; also in $\mathrm{Pa}$ which is the measure of the international measurement system (SI) and in which the mathematical calculations were carried out.

Pulleys

4 pulleys were used for the transition of movement from the motor to the belt, as well as a gear motor from 20 to 1 .

\section{RESULTS AND DISCUSSION}

According to the figures in time and number of handles placed during a shift, it was stipulated that there is a deficit of $25 \%$ in production.

Table 3 and table 4 are shown below with the time and production values manually and with the assembler.

Table 3 Evaluation of the manual method

\begin{tabular}{lllcc}
\hline & $\begin{array}{c}\text { Experien } \\
\text { ced staff }\end{array}$ & $\begin{array}{c}\text { Inexperie } \\
\text { nced staff }\end{array}$ & $\begin{array}{c}\text { Product } \\
\text { ion }\end{array}$ & $\begin{array}{c}\text { Expecte } \\
\text { d } \\
\text { product } \\
\text { ion }\end{array}$ \\
$\begin{array}{l}\text { Laying } \\
\text { time }\end{array}$ & 9 & 12 & & \\
$\begin{array}{l}\text { Product } \\
\text { ion per } \\
\text { shift }\end{array}$ & 3200 & 2400 & 7200 & 9500 \\
\hline
\end{tabular}

Table 4 Evaluation of the automatic method

\begin{tabular}{lcccc}
\hline & $\begin{array}{c}\text { Staf } \\
\text { f }\end{array}$ & $\begin{array}{c}\text { Productio } \\
\mathbf{n}\end{array}$ & $\begin{array}{c}\text { Productio } \\
\mathbf{n}\end{array}$ & $\begin{array}{c}\text { Expected } \\
\text { productio } \\
\mathbf{n}\end{array}$ \\
$\begin{array}{l}\text { Laying } \\
\text { time }\end{array}$ & 3 & & & \\
$\begin{array}{l}\text { Productio } \\
\text { n per shift }\end{array}$ & 960 & 9600 & 9500 & 9500 \\
\hline
\end{tabular}

Obviously, by automating the placement of the handle on the bottle, it is possible to reduce the placement time, in addition to meeting the objective of daily production.

To validate the efficiency of the proposed method, analysis of variance between the assembly methods is performed.

Where:

- H0: the assembly time does not depend on the method used.

- Continuous response variable which is time (in seconds).

- The categorical factor are the handle assembly methods.

\begin{tabular}{|c|c|c|c|c|c|c|c|}
\hline \multicolumn{8}{|l|}{ RESUMEN } \\
\hline Grupos & & Cuenta & Suma & & Promedio & & Varianza \\
\hline Columna 1 & & 10 & 81 & & & 8.1 & 3.65555556 \\
\hline Columna 2 & & 10 & 64 & & & 6.4 & 1.6 \\
\hline Columna 3 & & 10 & 41 & & & 4.1 & 0.76666667 \\
\hline \multicolumn{8}{|l|}{ ANÁLISIS DE VARIANZZA } \\
\hline Origen de las variaciones & Suma de cuadrados & Grados de libertad & Promedio de los cuadrados & $F$ & Probabilidad & & or critico para F \\
\hline $\begin{array}{l}\text { Entre grupos } \\
\text { Dentro de los grupos }\end{array}$ & 80.6 & $6 \quad 2$ & 40.3 & 20.0756458 & $4.55173 \mathrm{E}-06$ & & 3.354130829 \\
\hline Dentro de los grupos & 54.2. & & & & & & \\
\hline Total & 134.8 & 29 & & & & & \\
\hline
\end{tabular}

In the image 1 and 2 the value of the variance of each of the methods is observed, while in the second sample F calculated which is 20.0756458 and $F$ critical, when comparing the data it can be observed that the F calculated is greater than Critical F, therefore it is known that the hypothesis $\mathrm{HO}$ is rejected and it is concluded that the assembly time does depend on the method used.

The assembler fulfills the main purpose of reducing the time in the placement of handles on the bottles, covering the amount of production per shift and in turn, avoiding transfers of personnel due to bottle accumulation

\section{REFERENCES}

[1] Salvador, A. G. (1988). Introducción a la neumática Marcombo.

[2] Solé, A. C. (2011). Neumática y Hidráulica. Barcelona: Marcombo ediciones tecnicas .

[3] WilliamHanz. (20 de noviembre de 2017). E how En Español. Obtenido de https://www.ehowenespanol.com/chumacerasobre_544770/

[4] Arenales, J. C. (s.f.). Obtenido de http://biblio3.url.edu.gt/Libros/2013/ing/pim/3.pdf 
[5] Arenales, J. C. (s.f.). Obtenido de http://biblio3.url.edu.gt/Libros/2013/ing/pim/12.pdf

[6] Nistal, F. J. (2008). Automatismos eléctricos, neumáticos e hidráulicos. Editorial Paraninfo.

[7] Ruiz, A. O. (31 de Mayo de 2010). https://patents.google.com. Obtenido de https://patents.google.com: https://patentimages.storage.googleapis.com/3b/45/fe/117b 71938973a6/WO2010139835A1.pdf 